\title{
PERLINDUNGAN HUKUM TERHADAP TRANSAKSI $E$ COMMERCE LOVEBIRD BERDASARKAN UNDANG UNDANG NO 8 TAHUN 1999 TENTANG PERLINDUNGAN KONSUMEN
}

\author{
Anwar Sadad \\ Magister Hukum Universitas Semarang
}

\begin{abstract}
ABSTRAK
Tujuan dari penelitian ini adalah untuk menganalisa perlindungan hukum transaksi E CommerceLovebird. Permasalahan dalam penelitian ini adalah bagaimana Perlindungan Hukum Terhadap Transaksi E CommerceLovebird Berdasarkan Undang Undang No 8 Tahun 1999 Tentang Perlindungan Konsumen dan Problematika Perlindungan Hukum Terhadap Transaksi E CommerceLovebird Berdasarkan Undang Undang No 8 Tahun 1999 Tentang Perlindungan Konsumen, perlindungan hukum sangatlah dibutuhkan untuk meningkatkan wirausahawan. Metode yang digunakan dalam penulisan Penelitian ini menggunakan pendekatan yuridis normatif. Berdasarkan hasil penelitian dan analisis yang telah dilakukan dapat disimpulkan bahwa Perlindungan Hukum Terhadap Transaksi E CommerceLovebird mendapatkan perlindungan hukum berdasarkan pertama pasal $1243 \mathrm{KUH}$ Perdata jika penjual melakukan wanprestasi maka konsumen dapat melakukan gugatan ke Pengadilan Negeri Kedua Undang Undang No 8 Tahun 1999 Tentang Perlindungan Konsumen yakni berdasarkan pasal 62 Undang -undang Perlindungan Konsumen yang memberikan ancaman pidana terhadap pelaku usaha yang beriktikad tidak baik. Adapun problematika perlindungan Konsumen E CommerceLovebird terlatak pada dua aspek pertama tingkat kesadaran konsumen yang dirugikan dalam memperjuangkan hak-haknya selama ini masih rendah kedua Penegakan hukum terhadap produsen atau penjual barang terkait pelanggaran terhadap undang - undang konsumen masih kurang.
\end{abstract}

Kata Kunci: Perlindungan; konsumen; e-commerce lovebird 
$e-I S S N: 2621-4105$

\title{
LEGAL PROTECTION OF E COMMERCELOVEBIRD TRANSACTIONS BASED ON LAW NO 8 OF 1999 CONCERNING CONSUMER PROTECTION
}

\author{
Anwar Sadad \\ Master of Law, University of Semarang
}

\begin{abstract}
The purpose of this study is to analyze the legal protection of Lovebird E Commercetransactions. The problem in this study is how the Legal Protection of $E$ CommerceLovebird Transactions Based on Law No 8 of 1999 Concerning Consumer Protection and Problematics Legal Protection of E CommerceLovebird Transactions Based on Law No. 8 of 1999 concerning Consumer Protection, legal protection is urgently needed to increase entrepreneurs. The method used in writing this study uses a normative juridical approach. Based on the results of research and analysis that has been done it can be concluded that the Legal Protection of $E$ CommerceLovebird Transactions gets legal protection based on the first article 1243 Civil Code if the seller defaults then the consumer can file a lawsuit to the Second District Court Act No. 8 of 1999 concerning Consumer Protection namely based on article 62 of the Consumer Protection Act which provides criminal threats against business actors in bad faith. The problem of consumer protection in $E$ CommerceLovebird lies in the first two aspects, the level of awareness of consumers who are disadvantaged in fighting for their rights is still low. Second, law enforcement against producers or sellers of goods related to violations of consumer law is still lacking.
\end{abstract}

Keywords: Protection; consumer; lovebird e-commerce

\section{A. PENDAhuluan}

Dimasa sekarang ini, banyak orang berpendidikan yang memiliki modal untuk usaha, namun mereka lebih memilih menjadi pegawai di dunia kerja. Hal ini semakin mempersempit lapangan pekerjaan, karena tidak adanya jiwa enterpreneurship pada diri mereka. Ketakutan dan kebingungan mereka untuk melangkah mandiri atau berwirausaha sendiri membuat kemampuan yang mereka miliki menjadi tidak tersalurkan secara maksimal. Lulusan 
pendidikan tinggipun seakan tidak percaya dengan keterampilan mereka sendiri untuk menjadi seorang pemilik usaha bukan hanya pegawai usaha.

Fenomena semacam ini banyak terlihat di lingkungan masyarakat kita. Ketakutan akan kegagalan dan rasa tidak percaya pada kemampuan dirisendiri menjadi faktor utama berhentinya seseorang untuk menanamkan modal dalam bentuk wirausaha. Dampak negatif dari e-commerce itu sendiri cenderung merugikan konsumen. Diantaranya dalam hal yang berkaitan dengan produk yang dipesan tidak sesuai dengan produk yang ditawarkan, dan hal-hal lain yang tidak sesuai dengan kesepakatan sebelumnya. Contoh kasus saat belanja barang secara online, tapi barang yang dibeli tidak sama dengan yang dilihat difoto pada iklan yang dipajang. Apakah itu termasuk pelanggaran hak konsumen? Apakah dapat menuntut penjual untuk mengembalikan uang atau mengganti barang yang telah dibeli tersebut. Maka dari itu, dalam tulisan ini akan dipaparkan mengenai bagaimana perlindungan hukum yang seharusnya bagi konsumen dalam menghadapai kenyataan peristiwa yang sedang kekinian dan terbaru di jaman saat ini yakni tranksasi jual-beli secara E- Commerce berdasarkan ketentuan peraturan perundang-undangan yang mana telah tertuang dalam Undang- Undang Nomor 8 tahun 1999 tentang Perlindungan Konsumen (UUPK).

Transaksi jual beli online (e-commerce) juga merupakan suatu perjanjian jual- beli sama dengan jual beli konvensional yang biasa dilakukan masyarakat. Hanya saja terletak perbedaan pada media yang digunakan. Pada transaksi jual beli elektronik yang digunakan adalah media elektronik yaitu internet. Sehingga kesepakatan ataupun perjanjian yang tercipta melalui online. Menurut Efraim Turban "e-commerce is the process of buying, selling transferring, or exchanging product service and/or information via computer networks, mostly the Internet and intranets" Definisi tersebut diatas menjelaskan bahwa transaksi elektronik adalah proses pembelian, pengalihan penjualan, atau peningkatan pelayanan produk dan atau informasi melalui 
jaringan komputer, terutama internet dan intranet. Beberapa alasan konsumen berbelanja secara online yaitu karena praktis, karena tinggal "klik"e, isi data diri dan bayar lewat e-banking atau atm, hemat karena lebih murah dari retail di toko fisik, efisien karena tidak perlu keluar rumah naik kendaraan, cari parkir, dan bayar parkir atau taksi.

Burung Lovebird merupakan burung impor yang berasal dari Afrika dan Madagaskar. Burung Lovebird saat ini begitu populer di kalangan penggemar burung, Harganya pun bisa dinilai sangat tinggi karena budidaya dan perawatanya cukup mudah, Sehingga banyak orang yang tertarik menjadikan bisnis burung Lovebird sebagai pekerjaan sampingan bahkan pekerjaan utama. Transaksi e-commerce ini tidaklah mempertemukan penjual dan pembeli (konsumen) secara langsung dan konsumen pun tidak dapat melihat secara langsung barang yang ditawarkan. Hal ini kadangkala menimbulkan masalah yang merugikan konsumen, seperti barang tidak sesuai dengan katalog atau pengiriman barang telah mengakibatkan barang menjadi rusak.

\section{B. PERMASALAHAN}

Berdasarkan uraian latar belakang tersebut, dapat dirumuskan permasalahan sebagai berikut :

1. Bagaimana Perlindungan Hukum Terhadap Transaksi E Commerce Lovebird Berdasarkan Undang Undang No 8 Tahun 1999 Tentang Perlindungan Konsumen?

2. Bagaimana Problematika dan solusi Perlindungan Hukum Terhadap Transaksi E Commerce Lovebird Berdasarkan Undang Undang No 8 Tahun 1999 Tentang Perlindungan Konsumen.?

\section{Metode Penelitian}

1. Metode Pendekatan 
Metode yang dipergunakan dalam penulisan Penelitian ini menggunakan pendekatan penelitian yuridis normatif. Menggunakan pendekatan yuridis normatif oleh karena sasaran penelitian ini adalah hukum atau kaedah (norm). Pengertian kaedah meliputi asas hukum, kaedah dalam arti sempit (value), peraturan hukum konkret.Penelitian yang berobjekan hukum normatif berupa asas-asas hukum, sistem hukum, taraf sinkronisasi vertikal dan horisontal

2. Spesifikasi Penelitian

Penulisan ini tergolong dalam penelitian deskriptif. Suatu penelitian deskriptif, dimaksudkan untuk memberikan data yang seteliti mungkin tentang manusia, keadaan atau gejala-gejala lainnya. Maksudnya adalah terutama untuk mempertegas hipotesa-hipotesa, agar dapat membantu didalam memperkuat teori-teori lama, atau didalam kerangka menyusun teori-teori baru termasuk dalam spesifikasi penulisan hukum empiris yang bersifat deskriptif yaitu tehnik pengumpulan data yang bersifat pemaparan, bertujuan untuk memperoleh gambaran lengkap tentang keadaan hukum yang berlaku di tempat tertentu. Suatu penelitian diskriptif dimaksudkan untuk memberikan data yang seteliti mungkin tentang manusia, keadaan atau gejala-gejala lainnya .

Sifat penelitian yang digunakan dalam penulisan ini adalah penelitian yuridis normatif dengan menggunakan pendekatan kualitatif, dimana data yang diperoleh nantinya tidak berbentuk angka tetapi berupa kata-kata. Penelitian yuridis normatif yaitu penelitian yang dimaksudkan untuk memberikan data yang seteliti mungkin tentang manusia, keadaan, atau gejala-gejala lainnya. Maksudnya adalah terutama untuk mempertegas hipotesa - hipotesa, agar dapat memperkuat teori-teori lama, atau di dalam kerangka menyusun teori-teori baru .

\section{PEMBAHASAN}




\section{Perlindungan Hukum Terhadap Transaksi E Commerce Lovebird Berdasarkan Undang Undang No 8 Tahun 1999 Tentang Perlindungan Konsumen}

Berkembangnya teknologi informasi mempengaruhi aspek kehidupan manusia, termasuk dalam jual-beli dimana jual beli yang sebelumnya pembeli dan penjual bertemu dan bisa melihat barang yang diperjual belikan sekarang cukup dilakukan dengan diam duduk dirumah sembari melihat perangkat elektronik, lovebird adalah salah satu objek yang diperjualbelikan secara $E$ Commerce namun ada beberapa oknum yang berusaha meraup untung sebesar-besarnya bahkan rela menghalal kan berbagai cara untuk meraih keuntung. Untuk pemain lama mungkin hal ini tak berpengaruh apa-apa. Tetapi bagi pemula, tentu berbagai modus penipuanini sangatlah merugikan apalagi hal ini dilakukan secara e commerce, beberapa modus yang dilakukan penjual nakal lovebird secara $\mathrm{E}$ Commerceadalah sebagai berikut:

1. Modus mabung

Hati-hati ketika ada redaksi jual seperti ini "dijual burung asli gacor tapi sedang mabung, jadi lebih banyak diam". Modus penipuan seperti ini kerap kali terjadi. penjual sengaja beralasan mabung padahal burung nya memang tidak gacor. Sebenarnya meskipun sedang mabung, jika burung memang sudah gacor, burung tersebut tidak diam. burung tetap berbunyi gacor hanya saja biasanya dalam kondisi ngeriwik.

2. Modus pikok bulu

Modus ini biasanya digunakan untuk burung kacer betina yang disulap jadi laki-laki dengan cara dipikok bulu dada nya. Memang agak sulit membedakannya, cuma jika kita perhatikan secara teliti biasanya tubuh kacer betina agak montok. Kalo sudah 
biasanya pelihara burung kacer biasanya tahu bedanya meskipun di sulap

3. Modus Sepasang

Bagi pemula yang baru belajar ternak biasanya sering tertipu dengan modus yang satu ini. Terutama untuk jenis lovebird pasangan. Diiklankan sepasang jantan dan betina padahal satu jenis kelamin. Meskipun lovebird terlihat kawin, Karena lovebird kawin tidak jaminan jantan dan betina. Terlebih lagi untuk jenis lovebird yang memang terkenal sulit pembeda kelamin nya. Perhatikan juga klep nya ketika membeli, meskipun asli sepasang tetapi pasangan tersebut adalah klep dan non klep, percuma saja soal nya klep dan non klep itu infertil (sulit terjadi pembuahan). Ada tips jitu ketika ingin membedakan jenis kelamin dari lovebird secara kasat mata. Caranya adalah lihat garis putih pada lingkar paruh atas. Jika lingkar putih nya berbentuk lancip, bisa di pastikan itu jantan. Tetapi jika lingkar putihnya itu setengah lingkaran seperti parabola itu biasanya betina.

4. Modus bekas burung juara tetapi macet.

Modus ini sering dipakai untuk burung-burung gacor tetapi tidak punya mental ketika di lapangan. Alasannya burung bekas juara tetapi macet tidak mau bunyi. Ketika kita pantau, ternyata burung gacor.

5. Modus burung bahan pilih sendiri

Modus ini paling banyak terjadi untuk burung kenari bahan. Jadi burung kenari di ombyok di sangkar besar mirip ombyokan pleci. Kita disuruh memilih sendiri antara jantan dan betina acak. Aslinya burung kenari betina semua.

Kewajiban Penyelenggara Sistem Elektronik menerapkan manajemen resiko terhadap kerusakan atau kerugian yang ditimbulkan. 
Pelaku usaha penyelenggara transaksi elektronik juga memiliki kewajiban berdasarkan Pasal 49 Peraturan Pemerintah tentang Penyelenggaraan Sistem dan Transaksi Elektronik yang bunyinya sebagai berikut :

1. Pelaku Usaha yang menawarkan produk melalui Sistem Elektronik wajib menyediakan informasi yang lengkap dan benar berkaitan dengan syarat kontrak, produsen, dan produk yang ditawarkan;

2. Pelaku Usaha wajib memberikan kejelasan informasi tentang penawaran kontrak atau iklan;

3. Pelaku Usaha wajib memberikan batas waktu kepada konsumenuntuk mengembalikan barang yang dikirim apabila tidak sesuai dengan perjanjian atau terdapat cacat tersembunyi;

4. Pelaku Usaha wajib menyampaikan informasi mengenai barang yang telah dikirim

5. Pelaku Usaha tidak dapat membebani konsumen mengenai kewajiban membayar barang yang dikirim tanpa dasar kontrak

Undang-Undang Nomor 8 Tahun 1999 tentang Perlindungan Konsumen (selanjutnya disebut Undang-Undang Perlindungan Konsumen/UUPK), yaitu segala upaya yang menjamin adanya kepastian hukum untuk memberi perlindungan kepada konsumen . Kepastian hukum untuk memberikan perlindungan kepada konsumen itu antara lain adalah denga meningkatkan harkat dan martabat konsumen serta membuka akses informasi tentang barang dan/atau jasa baginya, dan menumbuhkan sikap pelaku usaha yag jujur dan bertanggungjawab

Tujuan yang ingin dicapai dalam perlindungan konsumen umumnya dapat dibagi dalam tiga bagian utama, yaitu:

a. Memberdayakan konsumen dalam memilih, menentukan barang dan/atau jasa kebutuhannya, dan menuntut hak-haknya (Pasal 3 huruf c); 
b. Menciptakan sistem perlindungan konsumenyang memuat unsur- unsur kepastian hukum, keterbukaan informasi, dan akses untuk mendapatkan informasi itu (Pasal 3 huruf d);

c. Menumbuhkan kesadaran pelaku usaha mengenai perlindungan konsumen sehingga tumbuh sikap jujur dan bertanggung jawab (Pasal 3 huruf e).

Pada hakikatnya, perlindungan konsumen menyiratkan keberpihakan kepada kepentingan-kepentingan (hukum) konsumen. Adapun kepentingan konsumen menurut Resolusi perserikatan bangsaBangsa Nomor 39/284 tentang Guidelines for Consumer Protection, sebagai berikut :

a. Perlindungan konsumen dari bahaya-bahaya terhadap kesehatan

b. Promosi dan perlindungan kepentingan sosial ekonomi konsumen

c. Tersedianya informasi yang memadai bagi konsumen untuk memberikan kemampuan mereka melakukan pilihan yang tepat sesuai kehendak dan kebutuhan pribadidan keamanannya

d. Pendidikan konsumen

e. Tersedianya upaya ganti rugi yang efektif

f. Kebebasan untuk membentuk organisasi konsumen atau organisasi lainnya yang relevan dan memberikan kesempatan pada organisasi tersebut untuk menyuarakan pendapatnya dalam proses pengambilan keputusan yang menyangkut kepentingan mereka.

Transaksi jual beli secara online atau melalui E-Commerce lovebird mempunyai kedudukan yang sama dengan jual beli secara tradisional yakni mengacu pasal $1243 \mathrm{KUH}$ Perdata jika penjual melakukan wanprestasi maka konsumen bisa melakukan gugatan ke Pengadilan Negeri. Transaksi jual beli lovebird meskipun dilakukan secara online, berdasarkan UU ITE dan PP PSTE tetap diakui sebagai transaksi elektronik yang dapat dipertanggungjawabkan. Kontrak Elektronik itu sendiri menurut Pasal 48 
ayat (3) PP PSTE setidaknya harus memuat hal-hal sebagai berikut; data identitas para pihak; objek dan spesifikasi; persyaratan Transaksi Elektronik; harga dan biaya; prosedur dalam hal terdapat pembatalan oleh para pihak; ketentuan yang memberikan hak kepada pihak yang dirugikan untuk dapat mengembalikan barang danatau meminta penggantian produk jika terdapat cacat tersembunyi. Terkait dengan perlindungan konsumen, Pasal 49 ayat (1) PP PSTE menegaskan bahwa Pelaku Usaha yang menawarkan produk melalui Sistem Elektronik wajib menyediakan informasi yang lengkap dan benar berkaitan dengan syarat kontrak, produsen, dan produk yang ditawarkan. Pada ayat berikutnya lebih ditegaskan lagi bahwa Pelaku Usaha wajib memberikan kejelasan informasi tentang penawaran kontrakatau iklan. Lalu muncul pertanyaan bahwa bagaimana jika barang bagi pihak konsumen tidak sesuai dengan yang diperjanjikan.

Penyelenggara Sistem Elektronik sebagai pelaku usaha wajib melakukan edukasi kepada Pengguna Sistem Elektronik sebagai konsumen, edukasi tersebut berkaitan dengan hak, kewajiban dan tanggung jawab seluruh pihak yang terkait, serta prosedur pengajuan komplain. Informasi yang wajib disampaikan oleh Penyelenggara Sistem Elektronik kepada Pengguna Sistem Elektronik sesuai dengan Pasal 25 Peraturan Pemerintah tentang penyelenggaraan Sistem dan Transaksi Elektronik yaitu mengenai Identitas Penyelenggara Sistem Elektronik, objek yang ditransaksikan, kenaikan atau keamanan sistem elektronik, tata cara penggunaan perangkat, syarat kontrak, prosedur mencapai kesepakatan dan jaminan privasi dan/atau perlindungan Data Pribadi.

Pasal 49 ayat (3) PP PSTE mengatur khusus tentang hal tersebut, yakni Pelaku Usaha wajib memberikan batas waktu kepada konsumen untuk mengembalikan barang yang dikirim apabila tidak sesuai dengan perjanjian atau terdapat cacat tersembunyi. Selain kedua ketentuan tersebut di atas, 
apabila ternyata barang yang diterima tidak sesuai dengan foto pada iklan toko online tersebut (sebagai bentuk penawaran), kita juga dapat menggugat Pelaku Usaha (dalam hal ini adalah penjual) secara perdata dengan dalih terjadinya wanpretasi atas transaksi jual beli yang Anda lakukan dengan penjual. Apabila pelaku usaha tidak melaksanakan kewajibannya, pelaku usaha dapat dipidana berdasarkan Pasal 62 UUPK, yang berbunyi“Pelaku usaha yang melanggar ketentuan sebagaimana dimaksud dalam Pasal 8, Pasal 9, Pasal 10, Pasal 13 ayat (2), Pasal 15, Pasal 17 ayat (1) huruf a, huruf b, huruf c, huruf e, ayat (2) dan Pasal 18 dipidana dengan pidana penjara paling lama 5 (lima) tahun atau pidana denda paling banyak Rp 2.000.000.000,00 (dua milyar rupiah)."

\section{Problematika dan solusi Perlindungan Hukum Terhadap Transaksi E Commerce Lovebird Berdasarkan Undang Undang No 8 Tahun 1999 Tentang Perlindungan Konsumen}

Problematika perlindungan hukum terhadap transaksi E Commerce Lovebird cenderung sama dengan transaksi E Commerce lainya yakni tingkat kesadaran konsumen yang dirugikan dalam memperjuangkan hakhaknya selama ini masih rendah. Hal ini tidak terlepas dari masih rendahnya pemahaman konsumen akan Undang - Undang Nomor 8 Tahun 1999 tentang Perlindungan Konsumen Konsumen harus mendapatkan penjelasan yang cukup tentang produk yang dibeli, jaminan mutu atas produk tersebut. Selain itu menjadikan konsumen cerdas dalam memilih produk, terutama menggunakan produk dalam negeri. Tujuannya meningkatkan harkat produk dalam negeri.

Penegakan hukum terhadap produsen atau penjual barang terkait pelanggaran terhadap undang - undang konsumen masih kurang maksimal dan masih jauh dari harapan, kelihatanya kejahatan dibidang konsumen kurang begitu mendapat perhatian dari aparat penegak hukum, sehingga penjual atau produsen yang nakal tidak merasakan balasan. Pelanggaran 
konsumen yang disebabkan oleh E Commerce dari luar negri maka Penyelesaian sengketa E-Commerce internasional dimungkinkan untuk diselesaikan terutama yang meliputi sengketa bernilai kecil dalam forum yang tepat, yaitu dengan Online Dispute Resolution (ODR), atau APS online yang menjadi cara praktis untuk memberi para pelanggan remedy yang tepat, murah dan efektif serta mengurangi penentuan perkara di negara asing. Ada beberapa keuntungan bagi pembeli dan pelaku usaha transaksi E-Commerce dalam penyelesaian sengketa melalui ODR

\section{E. PENUTUP}

Transaksi jual beli secara online atau melalui E-Commerce lovebird mempunyai kedudukan yang sama dengan jual beli secara tradisional yakni mengacu pasal 1243 KUH Perdata jika penjual melakukan wanprestasi yakni melakukan kelalaian atau kealpaan. Maka konsumen dapat melakukan gugatan wanprestasi selain mendapatkan perlindungan hukum dengan KUH Perdata Konsumen yang dirugikan $E$ Commerce Lovebird telah mendapatkan perlindungan melalui Undang Undang No 8 Tahun 1999 Tentang Perlindungan Konsumen yakni berdasarkan pasal 62 Undang -undang Perlindungan Konsumen yang memberikan ancaman pidana terhadap pelaku usaha yang beriktikad tidak baik, selain itu konsumen E Commerce Lovebird juga telah terlindungi dengan Peraturan Pemerintah No 82 tentang Penyelenggaraan Sistem dan Transaksi Elektronik yakni pasal 48 ayat (3). Problematika perlindungan hukum yang dihadapai konsumen $E$ CommerceLovebird dapat dibagi menjadi dua aspek pertama tingkat kesadaran konsumen yang dirugikan dalam memperjuangkan hak-haknya selama ini masih rendah. Hal ini tidak terlepas dari masih rendahnya pemahaman konsumen akan Undang - Undang Nomor 8 Tahun 1999 tentang Perlindungan Konsumen. konsumen cenderung pasrah akan nasibnya meskipun sudah dirugikan, konsumen cenderung tidak ingin tersita waktu dan tenaganya dan memperpanjang masalah apalagi kalau nilai kerugian sedikit. 
e-ISSN : 2621-4105

Kedua Penegakan hukum terhadap produsen atau penjual barang terkait pelanggaran terhadap undang - undang konsumen masih kurang maksimal dan masih jauh dari harapan, kelihatanya kejahatan dibidang konsumen kurang begitu mendapat perhatian dari aparat penegak hukum, sehingga penjual atau produsen yang nakal tidak merasakan balasan pidana ketika mereka melanggar undang-undang perlindungan konsumen. 


\section{DAFTAR PUSTAKA}

\section{BUKU}

Abdul Halim Barkatullah dan Teguh Prasetyo,2005.Bisnis E-Commerce: Studi Sistem Keamanan dan Hukum di Indonesia, Pustaka Pelajar, Yogyakarta,

A Nasution,1995 “Konsum dan Hukum”, Pustaka Sinar Harapan, Jakarta,

Budi Agus Riswandi,2003,Hukum dan Internet di Indonesia,Yogyakarta,UII Press

Dikdik M. Arief Mansur dan Elisatris Gultom,2005,Cyber Law (Aspek Hukum Teknologi Informasi),Bandung,Refika aditama

Dikdik M. Arief Mansur dan Elisatris Gultom,2005,Cyber Law (Aspek HukumTeknologi Informasi),Bandung,Refika aditama

Edmond Makarim,2003,Kompilasi Hukum Telematika,PT.RajaGrafindo

Elisatris Gultom,2002,Perlindungan Konsumen Dalam Transaksi ECommerce,Dalam Cyber law :Suatu Pengantar,Elips,Bandung

Elisatris Gultom,2002,Perlindungan Konsumen Dalam Transaksi ECommerce,Dalam Cyber law :Suatu Pengantar,Elips,Bandung

Esmi Warassih, 2005, Pranata Hukum sebuah Telaah Sosiologis, PT.Suryandaru Utama,Semarang

M.Sanusi Arsyad, 2000 "Transaksi Bisnis dalam Electronic Commerce (eCommerce):Studi Tentang Permasalahan - Permasalahan Hukum dan Solusinya”,Tesis Magister,Yogyakarta:Universitas Islam Indonesia,

Triton PB, 2006, Mengenal E-Commerce dan Bisnis di Dunia Cyber, Yogyakarta ,Author Publisher

Wiryono Prodjodikoro,1979,Asas-asas Hukum Perjanjian,Cetakan kedelapan,Bandung,Bale

Zoemrotin K.Susilo,1996,Penyambung Lidah Konsumen,Puspa Swara,Jakarta

\section{UNDANG-UNDANG}

Undang-undang Nomor 8 Tahun1999 tentang Perlindungan Konsumen.

Undang-undang Nomor 11 Tahun2008 tentang Informasi danTransaksi Elektronik.

Peraturan Pemerintah RepublikIndonesia Nomor 82 Tahun2012 tentang Penyelenggaraan Sistem dan Transaksi Elektronik.

\section{INTERNET}

http://validnews.co/Perkembangan-E-commerce-di-Indonesia--1--YXAiJ http://www.hukumonline.com/klinik/ dtail/lt50bf69280blee/perlindu ngan- 
Perlindungan Hukum Terhadap Transaksi E Commerce Lovebird Berdasarkan Undang Undang No 8 Tahun 1999 Tentang Perlindungan Konsumen

e-ISSN : 2621-4105

konsumen-dala-e- commerce

http://www.negarahukum.com/hukum/online-dispute- esolution.htm 